\title{
The Gap between the Beginning and the End of Algebraic Thinking Transition Period
}

\author{
1Dian Permatasari, ${ }^{2}$ Idris Harta \\ 1Universitas Negeri Yogyakarta, Jalan Colombo No.1 Caturtunggal Depok Sleman, Yogyakarta 55281, Indonesia \\ 2Universitas Muhammadiyah Surakarta, Jalan Ahmad Yani Pabelan Kartasura, Surakarta 57162, Indonesia \\ e-mail: dian.permatasari750@gmail.com
}

\begin{abstract}
Abstrak
Berpikir aljabar adalah elemen yang penting dalam berpikir matematika dan penalaran matematika. Siswa mengalami masa transisi menuju berpikir aljabar. Hal tersebut terjadi pada masa SD kelas V hingga SMP kelas VII. Penelitian ini bertujuan untuk mendeskripsikan perbedaan kemampuan berpikir aljabar siswa dari masa awal transisi, SD kelas V, hingga akhir masa transisi, SMP kelas VII. Penelitian ini merupakan penelitian cross-sectional dengan pendekatan mixed method. Hasil penelitian menunjukkan bahwa kemampuan berpikir aljabar siswa pada awal masa transisi, SD kelas V, berada dalam criteria sedang, dan kemampuan berpikir aljabar siswa pada akhir masa transisi, SMP kelas VII, berada dalam kriteria sedang. Rata-rata skor kemampuan berpikir siswa pada akhir masa transisi, SMP kelas VII lebih tinggi dibandingkan siswa SD kelas VI, namun kemampuan berpikir aljabar siswa SD kelas $V$ tidak jauh berbeda dengan siswa SMP kelas VII yaitu masih dalam kriteria sedang.
\end{abstract}

Kata kunci: berpikir aljabar, awal masa transisi, akhir masa transisi, cross-sectional

\begin{abstract}
Algebraic thinking is an important element in mathematics thinking and reasoning. All students experience a transition to algebraic thinking. It happens from elementary school grade $\mathrm{V}$ until junior high school grade VII. This study aims to describe the differences in algebraic thinking ability from the beginning of transition period, elementary school grade $V$, until the end of the transition period, junior high school grade VII. This research was a cross-sectional research using mixed method approach. The results showed that students' algebraic thinking ability at the beginning of the transition period and at the end of the transition period was in moderate criteria. The average score in algebraic thinking test at the end of the transition period, junior high school grade VII, was higher than the students in junior high school grade $\mathrm{V}$, but the algebraic thinking ability of students in elementary school grade $\mathrm{V}$ did not have much different with the students of junior high school grade VII, that was in the moderate criteria.
\end{abstract}

Keywords: algebraic thinking, the beginning of transition period, the end of transition period

How to Cite: Permatasari, D., \& Harta, I. (2018). The gap between the beginning and the end of algebraic thinking transition period. International Journal on Emerging Mathematics Education, 2(1), 79-88. http://dx.doi.org/10.12928/ijeme.v2i1.8655

\section{INTRODUCTION}

In every level of education, mathematics is one of the subjects that must be mastered by students. Mathematics has an important role to help students deal with daily life problems and develop students' logical thinking processes. In mathematics, there are some materials that must be mastered, one of them is algebra. Algebra is a way of expressing generalizations about numbers, quantities, relations, and functions (Watson, 2007). Taylor-Cox (2003) has the same idea, algebra is defined as generalization of arithmetic ideas in which unknown values and variables can be 
found to solve the problem. Thus, algebra is a generalization of arithmetical ideas related to statements with unknown variables and values to solve problem. Problem that can be solved with algebra is not only abstract problem but also problems in daily life presented in various contexts.

Algebra plays an important role in solving advanced mathematical problems, science, business, economics, commerce, computing and other issues in daily life (Booker, 2009). Therefore, algebra is one of the five content standards that is recommended by Principles and Standards of NCTM (2000). Therefore, students must study algebra from kindergarten to intermediate level. In general, Freudenthal (1977) argues that algebra is not only limited about symbols or variables. He stated that variables are more than just symbols in the form of letters, but algebra also includes 'relations' and relation is an important element of algebraic thinking. Algebra is not just a collection of facts and techniques, but a way of thinking (Lew, 2004).

According to Inganah (2016), thinking about algebra and algebraic thinking is different. The differences is thinking about algebra defined as the way used in symbol manipulation and algebraic thinking defined as a way to solve quantitative problems by analyzing relationships and using symbol Algebraic thinking is an essential and fundamental element of mathematical thinking and reasoning (Windsor, 2008). Algebraic thinking is the process by which students make relationships, find patterns from a particular mathematical contextual situation, and arrange generalizations through formal symbolic of representations and manipulations (Inganah, 2016).

Algebraic thinking involves various cognitive strategies to help student to understand the complex mathematical concepts. According to Driscoll (as cited in Panasuk, 2010), algebraic thinking is the capacity to represent a quantitative situation so the relationships between the variables become more visible. In the other hand, algebraic thinking can be defined as the use of any of a variety of representations in order to handle quantitative situations in a relational way (Kieran, 1998). Thus, algebraic thinking is the use of any of a variety of representations in order to generalize, represent, and solve quantitative situation.

There are three activities of school algebra based on students' activities while solving algebra problems (Kieran, 2004), there are generational activitiy involves the formation of statements and equations as objects of algebra. This activitiy includes equation containing an unknown to represent situation of the problems, expressions of generality arising from geometric patterns or numerical sequences, and expressions of the rules governing numerical relationships; transformational activitiy is related to change the form of statements or equations to maintain the equation. This activity includes collecting similar terms, factoring, expanding, substituting, adding and multiplying polynomial expressions, exponentiation with polynomials, solving equations, simplifying expressions, working with equivalent expressions and equations, and so on; and global meta-level activitiy is an activity in which algebraic activity is used as a tool but not really algebra is seen exclusively. This activitiy includes problem solving, modeling, noticing structure, studying change, generalizing, analyzing relationships, justifying, proving, and predicting activities that could be engaged in without using any algebra at all.

Algebraic thinking is the habit of mind of students acquired through continuous learning to support the ability to think, explain, and justify common relationships in arithmetic, geometry, and so on. In other words, algebraic thinking builds mathematical concepts. Therefore, algebraic thinking is very important for students. 
During the junior high school period approximately 6 years, students have learned about arithmetic. Students learn to work with numbers, number operations, and its properties in elementary school. According to Hidayanto (2014), the thinking process from elementary school grade 1 to grade $\mathrm{V}$ focuses on the process of arithmetic thinking, while the thinking process of junior high school grade VIII is demanded algebraic thinking. Therefore, from elementary school grade $\mathrm{V}$ to junior high school grade VII, there is a process of transition from arithmetic thinking to algebraic thinking gradually. Based on the results of research conducted by Cai \& Moyer (2008), the transition from arithmetic thinking to algebraic thinking is the most difficult step in the mathematical life of students. The transition from arithmetic thinking to algebraic thinking does not always go smoothly. Thus, students have to make many adjustments to learn algebra in high school. Based on the background and literature review, the purpose of this study is to identify the differences between students' algebraic thinking ability of elementary school grade $\mathrm{V}$ and junior high school grade VII.

\section{RESEARCH METHOD}

The type of this research is a cross-sectional study. Cross-sectional is one type of research that produces a 'snapshot' of the population at a particular point in time (Cohen et al., 2011). This research can be used to observe changes in mental development and student knowledge (Morgil \& Yörük, 2006). This research used mixed method approach with concurrent embedded strategy. This strategy used because quantitative and qualitative data are collected gradually, but analyzed simultaneously (Creswell, 2009).

This research was conducted in elementary and junior high school in Yogyakarta. The study was held in May to October 2017. The subjects of this study were 77 students of elementary school grade $V$ and 95 students of junior high school grade VII. Sampling technique used was stratified purposive technique. The technique was a combination of stratified sampling and purposive sampling. The stratified sampling is used to where the population was divided into several categories and then several samples are chosen with some consideration. The school category was based on mathematics score in the national examination and school examination and then it was divided into some category based on the Regulation Indonesian Ministry of Education and Culture number 5/2015 (Kemdikbud, 2015).

Table 1. School category criteria

\begin{tabular}{ccc}
\hline Category & Graduate Competency Level & Criteria \\
\hline A & Very High & $85<\overline{\mathrm{x}} \leq 100$ \\
B & High & $70<\overline{\mathrm{x}} \leq 85$ \\
C & Middle & $55<\overline{\mathrm{x}} \leq 70$ \\
D & Low & $\overline{\mathrm{x}} \leq 55$ \\
\hline
\end{tabular}

The data collected with test technique. The instrument is written test. The test includes 3 activies that is generational activity, transformational activity, and global meta-level activity. Each activity consists of 2 problems, so there are 6 algebraic thinking problem. The the test were given to 77 students of elementary school grade $V$ and 95 students of elementary school. After that, the result of the test is calculated based on established guidelines. Then, the average of gain score was changed in to qualitative value according to Azwar (2016) that is presented in Table 2. 
Table 2. Criteria for students' algebraic thinking ability

\begin{tabular}{cc}
\hline Interval & Criteria \\
\hline$X>M_{i}+S D_{i}$ & High \\
$M_{i}-S D_{i}<x \leq M_{i}+S D_{i}$ & Moderate \\
$x \leq M_{i}-S D_{i}$ & Low \\
\hline
\end{tabular}

In the Table $2, M_{i}$ is the ideal average score, which is calculated by $\frac{1}{2}$ of the sum of the highest score and the lowest score, while $S D_{i}$ is the deviation standard, which is calculated by $\frac{1}{6}$ of the difference of the highest score and the lowest score. Each activities have the ideal maximum score 10 , while the ideal minimum score is 0 . Then, the interval of algebraic thinking ability criteria is presented in Table 3 with $\mathrm{X}$ is the average of gain score.

Table 3. Criteria of algebraic thinking ability

\begin{tabular}{cc}
\hline Score & Criteria \\
\hline $\mathrm{X}>6.6$ & High \\
$3.4<\mathrm{X}<6.6$ & Moderate \\
$\mathrm{X} \leq 3.4$ & Low \\
\hline
\end{tabular}

After that, the data is presented in brief descriptions, tables, diagrams, relationships between categories in order to be easily understood.

\section{RESULTS AND DISCUSSION}

\section{The Student Algebraic Thinking Ability in the Beginning of Transition Period}

The beginning of transition period to have algebraic thinking ability is in elementary school grade $V$. The performance of students in elementary students grade $\mathrm{V}$ is presented in Table 4.

Table 4. Percentage of student algebraic thinking ability in elementary school grade $\mathrm{V}$

\begin{tabular}{cccc}
\hline School Category & Score Total & $\overline{\mathbf{x}}$ & Criteria \\
\hline $\mathrm{B}(n=28)$ & 158.3 & 5.7 & Moderate \\
C $(n=26)$ & 103.1 & 3.9 & Moderate \\
D $(n=23)$ & 96.1 & 4.1 & Moderate \\
Totally & 357.5 & 4.57 & Moderate \\
\hline
\end{tabular}

The average of gain score in algebraic thinking test of elementary school grade $\mathrm{V}$ is 4.67, which is in moderate criteria (see Table 4). Students in elementary school grade $\mathrm{V}$ are in the beginning of the transition from arithmetic thinking to algebraic thinking. Elementary school in B, C, and D category have the average of gain score consecutive $5.7 ; 3.9$; and 4.1 , which are in the moderate category. This is because algebraic thinking has been introduced in elementary school, but not formal algebraic thinking (Puspita et al., 2017). In addition, there are significant differences in agebraic thinking ability between schools in B, C, and D categories. Students in school with B category have a much higher algebraic thinking score score than other schools. This is because students in school with B category have been introduced about the use of symbols so that students can solve the given problems. 
The performance of elementary school grade $\mathrm{V}$ based on algebraic thinking activities are presented in Figure 1.

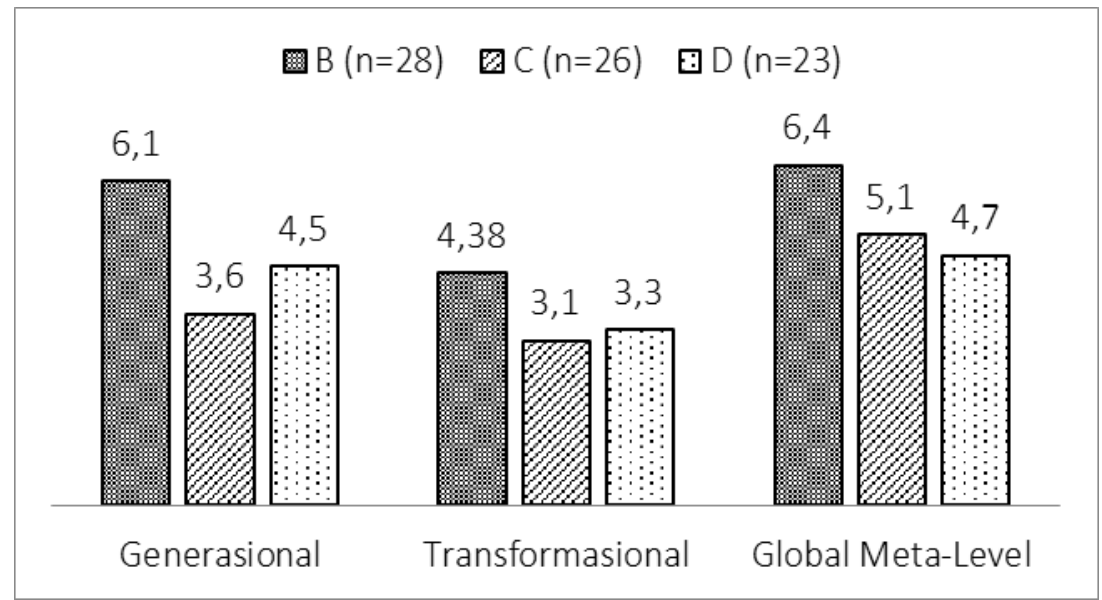

Figure 1 . The comparison of student score average based on activity type

Elementary students have the highest of the average scores in global meta-level activities. Since the thought of algebra introduced only relates to the basics for algebraic thinking such as solving problems (Puspita et al., 2017). In contrast, in transformational activities, students obtain the lowest algebraic thinking scores on average compared to other activities. This is because at the elementary school level, or unknown portion is not represented in the form of letters, usually not known symbolized by pictures or dots (Puspita et al., 2017).

\section{The Student Algebraic Thinking Ability in the Beginning of Transition Period}

The beginning of transition period to have algebraic thinking ability is in junior high school grade VII. The performance of students in junior high school grade VII is presented in Table 5.

Table 5. Percentage of junior high school students' results

\begin{tabular}{cccc}
\hline School Category & Score Total & $\overline{\mathbf{x}}$ & Criteria \\
\hline$A(n=31)$ & 219.8 & 7.1 & High \\
B $(\mathrm{n}=32)$ & 194.17 & 6.1 & Moderate \\
C $(\mathrm{n}=32)$ & 173.6 & 5.4 & Moderate \\
Totally & 587.57 & 6.2 & Moderate \\
\hline
\end{tabular}

The average of gain score in algebraic thinking test of junior high school grade VII is 6.2, which is in moderate criteria (see Table 5). The students of junior high school grade VII are at the end of the transition from arithmetic thinking to algebraic thinking. Students in junior high school especially grade VII have been introduced algebra like introduce symbol (Kemdikbud, 2016). Thus, students should be able to solve problems related to algebra. School with A, B, and C category have the average of gain score consecutive $7.1 ; 6.1$; and 5.4. School with A category have the average of gain score that higher than other categories, that is 7.1 and are in high criteria, while the $\mathrm{B}$ and $\mathrm{C}$ category schools are in the moderate category. 
The performance of students in junior high school grade VII based on algebraic thinking activities are presented in Figure 2.

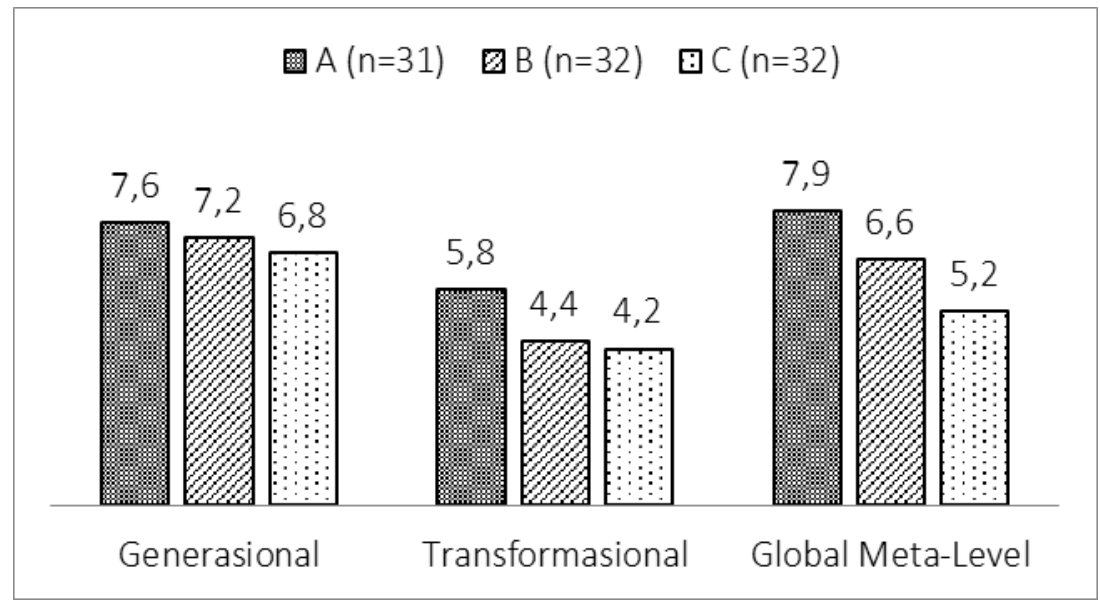

Figure 2. Average comparison of junior student scores by problem type

The highest average score is in generational activities and lowest on transformational activities. In generational activities, the averages of gain scores obtained by students in each category are at high criteria. Generational activity is an important part in algebraic thinking. According to Mason et al. (2005), every student who starts school has demonstrated the ability to generalize and abstract certain cases. Junior high school students are at a formal operational stage, so at this stage students can think more abstractly, ideally, and logical ways (Santrock, 2011). Students can use logic to solve problems (Feldman \& University, 2011). Thus, junior high school students who are already at a formal operational level where students can generalize the pattern well.

In the other hand, in the transformational activities of the students in each category the school obtained a lower average score than any other activity. This activity deals with the operation of variables to maintain equality. In this activity, students detach variables while performing algebraic operations (Drijvers et al., 2011). Therefore, junior high school students have the lowest average transformational activity scores compared to other activities.

\section{The Gap Between the Beginning and the End of Transition Period}

The results of students' answers to algebraic thinking ability are grouped according to school level, then it grouped again based on the school category. Overall student outcome from elementary school and junior high school is recorded in Table 6.

Table 6. Percentage of junior high school students' results

\begin{tabular}{|c|c|c|c|c|}
\hline \multirow[t]{2}{*}{ Answer Category } & \multicolumn{2}{|c|}{$\begin{array}{c}\text { Elementary school } \\
\text { grade V }\end{array}$} & \multicolumn{2}{|c|}{$\begin{array}{c}\text { Junior high school } \\
\text { grade VII }\end{array}$} \\
\hline & Response & $(\%)$ & Response & $\%$ \\
\hline Correct & 246 & $23 \%$ & 631 & $47 \%$ \\
\hline Incorrect & 702 & $65 \%$ & 595 & $45 \%$ \\
\hline No Answer & 130 & $12 \%$ & 104 & $8 \%$ \\
\hline Total & 1078 & $100 \%$ & 1330 & $100 \%$ \\
\hline
\end{tabular}

IJEME, Vol. 2, No. 1, March 2018, 79-88 
The average number of elementary students who answered correctly was $23 \%$ while for junior high school students it was $47 \%$ (see Table 5). Basically elementary students have been able to answer algebra issues correctly, which distinguishes them is the approach used by students to answer the problem. According to Hidayanto (2014), students from elementary grade V and junior high school grade VII experience a transition of thinking processes from arithmetic thinking to algebraic thinking gradually, from simple cases to complex cases. Grade V students can only solve simple cases whereas grade VII students must be able to solve more complex cases. the percentage of student answers base on educational level.

Table 7. The result of algebraic thinking test of Junior High School Grade VII based on activity type

\begin{tabular}{ccccccc}
\hline & \multicolumn{3}{c}{ Elementary School } & \multicolumn{2}{c}{ Junior High School } \\
Activity & \multicolumn{2}{c}{ grade V } & \multicolumn{2}{c}{ grade VII } \\
& TS & $\overline{\mathbf{x}}$ & Criteria & TS & $\overline{\mathbf{x}}$ & Criteria \\
\hline Generational & 370.0 & 4.8 & Moderate & 684.2 & 7.2 & High \\
Transformational & 280.8 & 3.6 & Moderate & 454.2 & 4.8 & Moderate \\
Global Meta-Level & 421.7 & 5.4 & Moderate & 624.2 & 6.6 & Moderate \\
Totally & 1072.5 & 4.6 & Moderate & 1762.6 & 6.3 & Moderate \\
\hline
\end{tabular}

There is a difference in algebraic thinking ability of grade $V$ elementary and junior high school students of grade VII (shown in Table 7). Elementary students have the highest average score on global meta-level activity, while junior high school students in generational activities. In elementary school, algebraic thinking was introduced only to the basics, such as solving problems (Puspita et al., 2017). While in the junior high school grave VII, students have been introduced to formal algebra, so that students think more abstractly, idealist, and logical ways (Santrock, 2011). Therefore, based on the result of, junior high school students who are already at the formal operational level have been able to generalize the pattern well (see Figure 3).

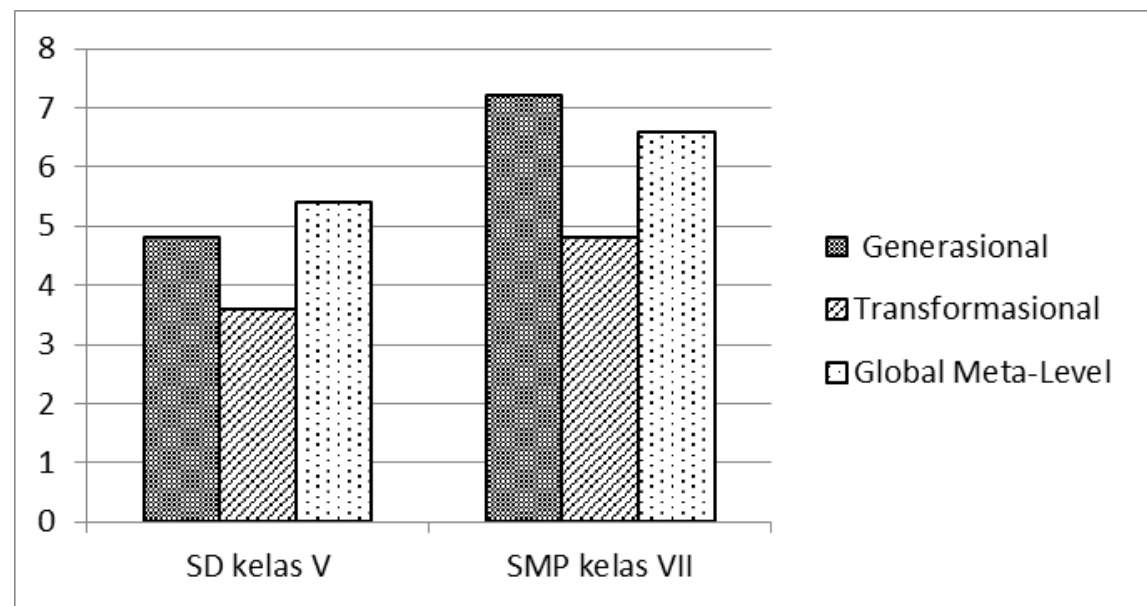

Figure 3. The comparison of Elementary School Grade V and Junior High School Grade VII based on activity type

The development of students' algebraic thinking abilities evolved over time Driscoll et al. (2003), as indicated by the difference in the percentage of students in 
correctly answering about the algebraic thinking ability provided. This is influenced by the material that has been obtained by students; junior high school students have obtained the material algebraically formally while elementary students have not been formally introduced. Therefore, the ability of elementary students in solving algebra problems still in the moderate category. There is not much different from junior high school students.

\section{CONCLUSION}

In the beginning of the transition of algebraic thinking, the algebraic thinking ability of elementary students grade V is in moderate criteria. Students in elementary students grade $\mathrm{V}$ have the highest average of gain scores on global meta-level activities because algebraic thinking has been introduced in elementary school, while the lowest average is on transformational activities. It is because algebraic thinking has been introduced but only deals with the basics for algebraic thinking especially in solving simple problems. In the end of the transition period, the students algebraic thinking ability of junior high school grade VII is in the moderate criteria. Students in junior high school grade VII have the highest average of gain score on generational activities and the lowest on transformational activities. It is because algebraic thinking has been formally introduced in junior high school grade VII and is in a formal operational thinking stage where students can already think abstractly and logically. Although, it is necessary to develop learning process and teaching materials that can improve students' algebraic thinking ability at all levels, especially where students transition from arithmetic thinking to algebraic thinking. The teaching material, such as lesson plan, book, and etc, must facilitate algebraic thinking and teachers must be understand the ability of the student in transition period of arithmetic thinking to algebraic thinking.

The development of students' algebraic thinking ability develops over time. Elementary school grade V and junior high school grade VII undergo a transition of arithmetic thinking to algebraic thinking gradually, from simple cases to more complex cases. It is influenced by the material that has been obtained by students, students in junior high school grade VII have obtained the material algebraically formally while elementary students grade $\mathrm{V}$ have not been formally introduced. Therefore, the ability of elementary students in solving algebra problems still in the moderate category is not much different from junior high school students. This research is a cross-sectional study which means only take 'snapshot' from the population at certain point in time, so it needs further research in the form of longitudinal research such as how students think process in transition period, that is how students in generalize pattern, how the process of student in finding inter patterns, and how the process in making an equation of a situation in more detail.

\section{REFERENCES}

Azwar, S. (2016). Tes prestasi: Fungsi dan pengembangan pengukuran prestasi belajar. Yogyakarta: Pustaka Belajar.

Booker, G. (2009). Algebraic thinking: Generalising number and geometry to express patterns and properties succinctly. Brisbane: Griffith University.

Cai, J., \& Moyer, J.C. (2008). Developing algebraic thinking in earlier grades: Some insights from international comparative studies. In C. Greenes \& R. Rhubenstein (Eds.), Algebra and algebraic thinking in school mathematics (pp. 169-182). Reston, VA: National Council of Teachers of Mathematics. 
Cohen, L., Manion, L., \& Morrison, K. (2011). Research methods in education (7th ed.). New York: Routledge.

Creswell, J. W. (2009). Research design: Qualitative, quantitative and mixed approaches (3rd ed.). California: SAGE Publications, Inc.

Drijvers, P., Goddijn, A., \& Kindt, M. (2011). Algebra education: Exploring topics and themes. In P. Drijvers (Ed.), Secondary algebra education: Revisiting topics and themes and exploring the unknown. Rotterdam: Sense Publishers.

Driscoll, M., Zawojeski, J., Humez, A., Nikula, J., Goldsmith, L., \& Hammerman, J. (2003). The fostering algebraic thinking toolkit: A guide for staff development. Arlington, VA: EDRS.

Feldman, R.S., \& University, R.S.F. (2011). Understanding psychology (10th ed.). New York: McGraw-Hill.

Freudenthal, H. (1977). What is algebra and what has it been in history? Archive for History of Exact Sciences, 16(3), 189-200.

Hidayanto, E. (2014). Transisi dari berpikir aritmetis ke berpikir aljabaris. Dissertation. Malang: Universitas Negeri Malang.

Inganah, S. (2016). Karakteristik berpikir aljabar siswa pada level multi struktural dalam menggeneralisasi pola. Proceeding of Seminar Nasional dan Gelar Produk (Senaspro), Malang, 305-314.

Kemdikbud. (2015). Permendikbud No. 5 Tahun 2015 tentang Kriteria Lulusan Peserta Didik, Penyelenggaraan Ujian Nasional, dan Penyelenggaraan Ujian Sekolah/Madrasah/Pendidikan Kesetaraan Pada SMP/Mts atau Yang Sederajat Dana SMK/MA/SMK atau Yang Sederajat. Jakarta: Kementerian Pendidikan dan Kebudayaan.

Kemdikbud. (2016). Permendikbud Nomor 24 Tahun 2016 Kompetensi Inti Dan Kompetensi Dasar Pelajaran Pada Kurikulum 2013 Pada Pendidikan Dasar dan Pendidikan Menengah. Jakarta: Kementerian Pendidikan dan Kebudayaan.

Kieran, C. (1998). The changing face of school algebra. Proceeding of 8th International Congress on Mathematics Education, Sevilla, 271-290.

Kieran, C. (2004). Algebraic thinking in the early grades : What is it? The Mathematics Educator, 8(1), 139-151.

Lew, H. (2004). Developing algebraic thinking in early frades: Case study of korean elementary school mathematics. The Mathematics Educator, 8(1), 88-106.

Mason, J., Graham, A., \& Johnston-Wilder, S. (2005). Developing thinking in algebra. London: Paul Chapman Publishing.

Morgil, I., \& Yörük, N. (2006). Cross-age study of the understanding of some concepts in chemistry subjects in science curriculum. Turkish Science Education, 3(1), 1527.

NCTM. (2000). Principles and standards for school mathematics. Reston, VA: The National Council of Teachers of Mathematics.

Panasuk, R.M. (2010). Three phase ranking framework for assessing conceptual understanding in algebra using multiple representations. Education, 131(2), 235-257. 
Puspita, I., Kaniawati, I., \& Suwarma, I.R. (2017). Student obstacles in solving algebraic thinking problems. Journal of Physics Conference Series, 895(1), 1-6.

Santrock, J.W. (2011). Educational psychology (5th ed.). New York: McGraw-Hill.

Taylor-Cox, J. (2003). Algebra in the Early Years? Yes! Young Children, 58(1), 14-21.

Watson, A. (2007). Algebraic Reasoning. In W. Morris (Ed.), Key understandings in mathematics learning (pp. 186-227). London: Nuffield Foundation.

Windsor, W. (2008). Algebraic thinking : A problem solving approach. Proceeding of the 33rd Annual Conference of the Mathematics Education Research Group of Australasia, Freemantle, 665-672. 